\title{
Diversity of Periphytic Communities in Lakes of Karelian Isthmus
}

\author{
Elena V. Stanislavskaya* \\ Institute of Limnology RAS \\ 9 Sevastianova Str., Saint-Petersburg, 194106, Russia
}

Received 04.02.2017, received in revised form 06.02.2017, accepted 10.03.2017

This paper describes the results of an investigation of taxonomic composition, community structure and dominant species of periphytic algae in 30 lakes located in different geomorphic regions of Karelian Isthmus. Structure of periphyton communities was studied in summer 2011-2013. In summer periphyton communities there were 400 algal taxa, most of which were diatoms and green algae. There was significant variability of taxonomic structure in the lakes of different trophic state. In oligotrophic lakes with low productivity, rare green algae and cyanobacteria species dominated in periphytic communities, whereas in meso- and eutrophic lakes diatom and green algae taxa with wide ecological requirements were dominant.

Keywords: periphyton, lakes, taxonomic composition, dominant species, Karelian Isthmus.

Citation: Stanislavskaya E.V. Diversity of periphytic communities in lakes of Karelian Isthmus. J. Sib. Fed. Univ. Biol., 2017, 10(1), 35-48. DOI: 10.17516/1997-1389-0006.

\section{Разнообразие перифитонных сообществ \\ в озерах Карельского перешейка}

Е.В. Станиславская

Институт озероведения РАН

Россия, 194106, Санкт-Петербург, ул. Севастьянова, 9

Приведены результаты изучения таксономического состава, структуры и доминирующих видов водорослей перифитона 30 разнотипных озер Карельского перешейка, расположенных в различных геоморфологических районах. В летний период 2011-2013 г2. в перифитоне выявлено

(C) Siberian Federal University. All rights reserved

* Corresponding author E-mail address: stanlen@mail.ru 
400 таксонов, среди которых преимущественное значение имели диатомовые и зеленые водоросли. В озерах различного трофического уровня наблюдалась значительная изменчивость структуры фитоперифитона. В олиготрофных и малопродуктивных озерах в комплексе доминирующих видов преобладали редко встречающиеся зеленые водоросли и цүианобактерии, тогда как в мезотрофных и эвтрофных это были диатомовые и зеленые водоросли широкого экологического спектра.

Ключевые слова: перифитон, озера, видовой состав, доминирующие видь, Карельский перешеек.

\section{Введение}

Водоросли обрастаний являются чувствительным компонентом автотрофного звена любых водоемов и характеризуют условия среды своего обитания. Таксономический состав, эколого-географические спектры, комплексы доминирующих видов водорослей отражают процессы, идущие в водоеме и на его водосборе. Для выявления биотических и абиотических факторов, влияющих на формирование альгофлоры, перспективно сравнение разнотипных водоемов, расположенных на определенной территории. Карельский перешеек представляет своего рода «полигон» для выполнения таких исследований. Относительно небольшая протяженность Карельского перешейка и разнообразие ландшафтов определяют широкий спектр водоемов, в которых возникают условия для появления и развития разнообразной альгофлоры. К настоящему времени водоросли перифитона озер Карельского перешейка все еще недостаточно изучены (Лукницкая, 2011). Наиболее подробно эта экологическая группа водорослей исследована в озере Красном, где наблюдения начались еще в 70-х гг. прошлого столетия: имеются данные о видовом составе, массовых видах, количественных показателях, о сезонной и межгодовой изменчивости этих характеристик (Басова, 1976; Станиславская, 2008). В те же годы был изучен состав и распространение перифитона в озерах
Борисовском, М. Луговом, Охотничьем, Нахимовском, Снетковском, расположенных на Центральной возвышенности Карельского перешейка (Станиславская, Трифонова, 1984). В конце 80-х гг. подробно исследовался перифитон озер Б. Ракового, Глубокого, Охотничьего (Станиславская, 1999). Имеются сведения о массовых видах и продукционных характеристиках перифитона озер Вишневского и Б. Ракового (Трифонова и др., 1998; Trifonova et al., 2002). Помимо обрастаний озер есть данные о перифитоне рек, протекающих по территории Карельского перешейка (Никулина, 1976; Комулайнен, 2004; Станиславская, 2004, 2006; Станиславская, Горченко, 2005). Исследовали видовой состав и распространение зигнемовых водорослей, в том числе и обрастаний, на особо охраняемых природных территориях (ООПТ) Карельского перешейка (Лукницкая, 2011).

Основной целью данной работы было изучение таксономического состава, структуры и доминирующих водорослей перифитона, а также выявление различий этих показателей в озерах разного трофического уровня.

\section{Материалы и методы}

Территория Карельского перешейка расположена на стыке двух крупных геоморфологических областей: Балтийского кристаллического щита и Русской равнины. Это определяет резкую неоднородность его геоло- 
гического строения и большое разнообразие ландшафтов (Исаченко и др., 1965; Трифонова, 1990). Наиболее четко выделяются районы Выборгского сельгового ландшафта (в Карелии и Финляндии сельгами называют гряды/ валы вытянутых возвышенностей ледникового происхождения), Западного Приладожья, Центральной возвышенности и Приморского ландшафта (рис. 1).

Все исследованные озера имеют различные водосборы, морфометрию, степень зарастания и трофический статус (табл. 1). Они, как правило, ледникового происхожде- ния, имеют разнообразную форму котловин, их размер изменяется от 0,2 до 10,5 км². Глубины озер варьируют в широких пределах: наиболее мелководны (от 1,5 до 3 м) озера Приморского ландшафта, в озерах других районов глубины изменялись от 1,5 до 20 м. Озера имеют слабую минерализацию (от 20 до 100 мг/л), относятся к гидрокарбонатному классу, группе кальция. В некоторых заболоченных озерах Центральной возвышенности отмечается высокое содержание разных форм железа, а также органического вещества гумусового происхождения, что приводит к

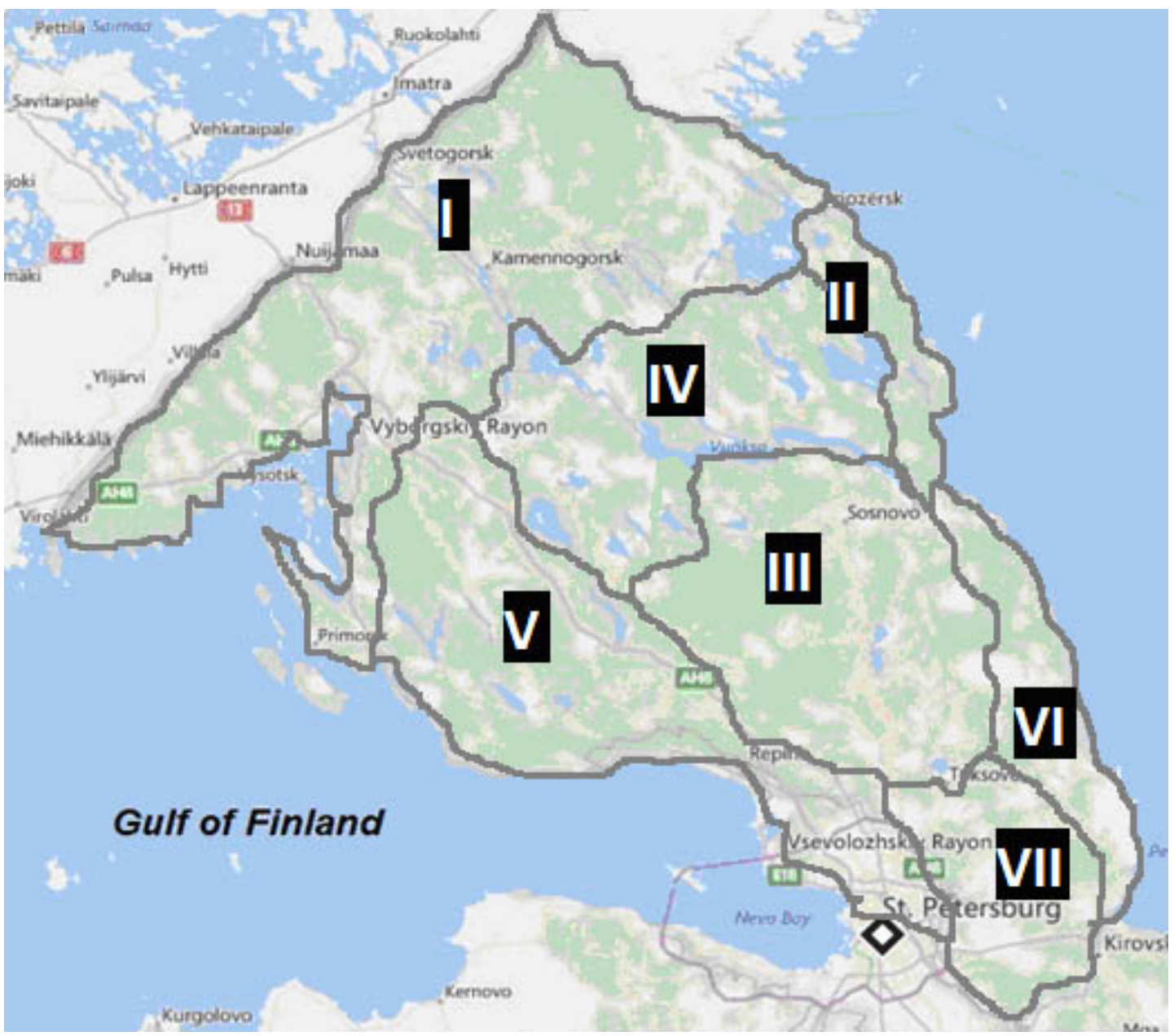

Рис. 1. Карта-схема ландшафтных районов Карельского перешейка: I - Выборгский (сельговый) ландшафт; II - Северо-Западное Приладожье; III - Центральная возвышенность; IV - Привуоксинская низина; V - Приморский ландшафт; VI - Южное Приладожье; VII - Приневская низменность 
Таблица 1. Список исследованных озер и их трофический статус

\begin{tabular}{|c|c|c|}
\hline Тип ландшафта & Название озер & Трофический тип \\
\hline $\begin{array}{l}\text { Выборгский (сельговый) } \\
\text { ландшафт }\end{array}$ & $\begin{array}{l}\text { Бородинское } \\
\text { Лесково } \\
\text { Б. Заветное } \\
\text { Горское } \\
\text { Б. Богородское }\end{array}$ & $\begin{array}{l}\text { Мезотрофное } \\
\text { Мезотрофное } \\
\text { Мезотрофное } \\
\text { Мезотрофное } \\
\text { Олиготрофное }\end{array}$ \\
\hline Северо-Западное Приладожье & $\begin{array}{l}\text { Снетковское } \\
\text { Воробьево } \\
\text { Нарядное } \\
\text { Щукинское } \\
\text { М. Бережное }\end{array}$ & $\begin{array}{l}\text { Олиготрофное } \\
\text { Олиготрофное } \\
\text { Олиготрофное } \\
\text { Слабомезотрофное } \\
\text { Олиготрофное }\end{array}$ \\
\hline Центральная возвышенность & $\begin{array}{l}\text { Светлое } \\
\text { Берестовое } \\
\text { Узорное } \\
\text { Б. Морозовское } \\
\text { М. Луговое } \\
\text { Б. Луговое } \\
\text { Медведевское } \\
\text { Сиркоярви } \\
\text { Мичуринское } \\
\text { Журавлевское } \\
\text { Вишневское } \\
\text { Волочаевское }\end{array}$ & $\begin{array}{l}\text { Слабомезотрофное } \\
\text { Олиготрофное } \\
\text { Слабомезотрофное } \\
\text { Эвтрофное } \\
\text { Мезотрофное* } \\
\text { Мезотрофное* } \\
\text { Мезотрофное* } \\
\text { Мезотрофное } \\
\text { Мезотрофное } \\
\text { Эвтрофное } \\
\text { Гиперэвтрофное } \\
\text { Гиперэвтрофное }\end{array}$ \\
\hline Приморский ландшафт & $\begin{array}{l}\text { Чернявское } \\
\text { Б. Лебяжье } \\
\text { Красногвардейское } \\
\text { М. Лозовое } \\
\text { Затишье } \\
\text { Балаково } \\
\text { М. Ладога } \\
\text { Б. Симагинское }\end{array}$ & $\begin{array}{l}\text { Мезотрофное } \\
\text { Эвтрофное } \\
\text { Эвтрофное } \\
\text { Дистрофное** } \\
\text { Дистрофное** } \\
\text { Гиперэвтрофное } \\
\text { Гиперэвтрофное } \\
\text { Мезотрофное }\end{array}$ \\
\hline
\end{tabular}

Примечание: *- полигумозные озера, **-мезогумозные озера.

высокой цветности и вызывает снижение pH. В таких мезогумозных озерах цветность в среднем составляет $150^{\circ} \mathrm{Pt} / \mathrm{Co}$ шкалы, а в полигумозных озерах она может достигать $500^{\circ}$ Pt/Cо шкалы. В этих же озерах, как правило, отмечались низкие рН воды $(4,8-6,1)$, тогда как в большинстве озер они были в пределах 7-7,8. Наиболее высокими величинами $\mathrm{pH}$ воды отличались эвтрофные и гиперэвтрофные озера Приморского ландшафта $(8,5-9,9)$, где наблюдалось «цветение» воды. В них же были отмечены наиболее высокие концентрации биогенных элементов $\left(\mathrm{P}_{\text {общ }}-350\right.$ мкг/л, $\mathrm{N}_{\text {общ }}-2$ мг/л). Наиболее низким содержанием биогенных элементов характеризуются озера

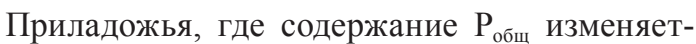
ся в пределах 7-15 мкг/л, а $\mathrm{N}_{\text {общ }}-0,5-0,7$ мг/л (Трифонова, 2014). Хозяйственное освоение региона с увеличением дачного и загородного строительства на большей части территории Карельского перешейка ведет к усилению антропогенного пресса на экосистемы большинства озер с повышением их трофического статуса. Однако в сельговом районе и Приладожье еще сохранились озера, которые можно отнести к разряду олиготрофных и слабомезотрофных. На Центральной возвышенности встречались озера всех трофических типов. 
Большинство озер, расположенных в районе Приморского ландшафта, отличались высоким уровнем трофии (табл. 1).

Материалом для работы послужили сборы водорослей перифитона, которые проводились в июле 2011-2013 гг. на 30 разнотипных озерах (табл. 1). Водоросли перифитона собирали с воздушно-водной (тростники, хвощи), с плавающими листьями (кубышки) и погруженной (рдесты, элодея) растительности. Для сбора и обработки материала использовали методики, применяемые на протяжении ряда лет (Станиславская, Трифонова, 1984). Подводные части растений срезали и помещали в 1-2 л профильтрованной озерной воды. Затем водоросли соскабливали с помощью зубной щетки. Полученную после фиксации 40\%-ном формалином взвесь водорослей использовали для определения видового состава, численности и биомассы. Пробы просматривали в камере Нажжота объемом 0,05 мл с использованием микроскопов AxioLab A1 и AxioVert CFL 40 (Carl Zeiss). Биомассу pacсчитывали объемным методом, приравнивая объемы клеток водорослей к объемам сходных геометрических фигур. Определение водорослей проводилось по определителям (Определитель пресноводных водорослей CCCP, 1951-1986; Царенко, 1990; Krammer, Lange-Bertalot, 1986, 1988, 1991a,b; Komarek, Anagnostidis, 1999). Индекс видового разнообразия Шеннона рассчитывали по биомассе. В комплекс доминирующих видов включали виды, определяющие не менее 10 \% от общей биомассы (Станиславская, Трифонова, 1984).

\section{Результаты и обсуждение}

Всего за период исследований в составе летнего перифитона было выявлено 400 таксонов водорослей, принадлежащих к 6 отделам: Bacillariophyta - 177 (44 \%) таксонов, Chlorophyta - 145 (36 \%), Cyanobacteria
(Cyanophyta) - 60 (15\%), Euglenophyta - 10 (2,5\%), Xanthophyta - 5 (1,5\%), Rhodophyta 3 (1 \%). Подобное распределение таксонов в перифитоне характерно для многих водоемов и водотоков Северо-Западного региона, водоемов Белоруссии и других регионов умеренной зоны (Никулина, 1976; Комулайнен, 1996, 2004; Метелева, 2001; Глущенко, Гольд, 2008; Судницына, 2008; Губелит, Никулина, 2009; Макаревич и др., 2013; Беляева, 2014).

Отдел диатомовых водорослей был представлен 177 видовыми и внутривидовыми таксонами из 35 родов. В перифитоне мезотрофных и эвтрофных озер встречались и зачастую играли важную роль в сложении биомассы центрические диатомеи родов Aulacoseira, Cyclotella, Stephanodiscus, Cyclostephanos, a также Melosira varians C. Agardh и M. undulata (Ehrenberg) Kützing. Пеннатные диатомеи, которые составляли $90 \%$ общего количества видов диатомовых водорослей, были широко распространены во всех исследованных озерах. По числу таксонов выделялись роды Fragilaria (25), Gomphonema (20), Eunotia (18), Cymbella (18), Pinnularia (11), Navicula (10), Nitzschia (10), Epithemia (8). В озерах всех трофических типов постоянно встречались и нередкодоминировалитакиевиды, как Tabellaria flocculosa (Roth) Kützing, T. fenesrata (Lyngbye) Kützing, Ulnaria ulna (Nitzsch) Compère, Fragilaria capucina Desmazieres, F. construens (Ehrenberg) Grunov, Eunotia pectinalis (Kützing) Rabenhorst, E. serra Ehrenberg, Gomphonema truncatum Ehrenberg, G. acuminatum Ehrenberg, G. brebissonii Kützing, Cymbella cistula (Ehrenberg) Kirchner, C. cymbiformis C. Agardh, C. lanceolata (Ehrenberg) Kirchner, Navicula radiosa Kützing, $N$. cryptocephala Kützing, $N$. rhynchocephala Kützing. Представители родов Tabellaria и Eunotia являются массовыми и ведущими видами во многих водоемах Карелии и Крайнего Севера (Губелит, Никулина, 2009; 
Стенина, 2009; Денисов, 2011; Chekryzheva, Komulainen, 2010).

Не менее разнообразными в исследованных озерах были зеленые водоросли, всего было определено 145 видовых и внутривидовых таксонов из 30 родов. Лидирующую роль в биомассе играли зеленые нитчатые водоросли из родов Oedogonium и Bulbochaeta. Виды рода Oedogonium встречались в большинстве исследованных озер, а виды рода Bulbochaeta более распространены в малопродуктивных озерах. Представители родов Stigeoclonium, Klebsormidium, Microspora, Chaetophora были менее разнообразны по количеству видов, но часто входили в состав ведущих комплексов обрастаний в озерах разного типа. Зигнемовые водоросли родов Spirogyra, Mougeotia, Zygnema были, как правило, стерильны и не идентифицированы до вида. Наибольшее распространение они имели в слабомезотрофных, мезотрофных и слабоэвтрофных озерах. Среди десмидиевых водорослей наибольшее количество таксонов отмечено у родов Cosmarium (25), Closterium (15) и Euastrum (10). Значительно ниже была видовая насыщенность родов Staurastrum (6), Micrasterias (5), Cosmoastrum (5), Staurodesmus (5), Pleurotaenium (2). Наибольшее количество видов десмидиевых водорослей отмечалось в озерах на севере Карельского перешейка. Значительное развитие этих водорослей связано с тем, что они предпочитают водоемы с низкой минерализацией и невысоким содержанием биогенных элементов, которые находятся у выходов кристаллических пород (Трифонова, 1990; Лукницкая, 2011). В перифитоне эвтрофных озер всех ландшафтов отмечались планктонные хлорококковые водоросли из родов Monoraphidium, Pediastrum, Scenedesmus, Coenocystis, но разнообразие их было невелико.
Cyanobacteria - третья по таксономическому разнообразию группа в перифитоне: 60 видов и подвидов из 25 родов. Хроококковые отличались небольшим разнообразием Microcystis (4), Merismopedia (4), Chroococcus (4), которые чаще встречались в перифитоне эвтрофных и гиперэвтрофных озер всех ландшафтов. Более разнообразными были гормогониевые, среди которых выделялись ностоковые, широко распространенные в исследованных озерах всех ландшафтов, особенно родов Anabaena (8), Rivularia (4), Calothrix (4), Tolypothrix (4), Gloeotrichia (3) и Nostoc (3). Видовая насыщенность стигонемовых - Hapalosiphon, Stigonema, Fischerella была ниже, и они, как правило, доминировали в малопродуктивных озерах сельгового ландшафта, Приладожья и Центральной возвышенности. Представители родов Calothrix, Tolypothrix, Stigonema, Nostoc занимали лидирующее по встречаемости положение в большинстве рек и наземных биоценозах в Карелии (Комулайнен, 2008). Осциллаториевые родов Oscillatoria (8), Lyngbya (6), Phormidium (4) были характерны для эвтрофных и гиперэвтрофных озер Центральной возвышенности и приморского ландшафта. Некоторые из этих видов в массе развиваются в фитопланктоне исследованных водоемов и являются причинами «цветения» воды (Трифонова и др., 2014).

Отдел эвгленовых водорослей был представлен родами Euglena (4), Trachelomonas (4), Phacus (2), виды которых встречались в основном в эвтрофных и гиперэвтрофных озерах. Представители желто-зеленых водорослей были также немногочисленны, таксоны рода Tribonema (5) отмечались в перифитоне озер единично. Разнообразие красных водорослей в озерах Карельского перешейка невелико по сравнению с водоемами и водотоками Карелии (Комулайнен, 2008; Chekryzheva, Komulainen, 
2010). Всего было обнаружено 3 вида этого отдела: Batrachospermum moniliforme Roth, Sirodotia sueticum Kylin, Lemanea fluviatilis (Linnaeus) C. Agardh, которые встречались в озерах Приладожья.

Наиболее низкая видовая насыщенность отмечена в перифитоне полигумозных, дистрофных и гиперэвтрофных озер, где на разных типах растительности наблюдали от 7 до 12 таксонов водорослей, тогда как в мезотрофных и эвтрофных озерах она была заметно выше - от 20 до 40 таксонов. Наибольшее количество таксонов (40-60) выявлено в олиготрофных малопродуктивных водоемах. Как правило, таксономическое разнообразие было невелико в перифитоне на растениях с плавающими листьями и увеличивалось на погруженной растительности в основном за счет увеличения доли планктонных и бентосных форм в составе обрастаний.

При географическом анализе альгофлоры часто используют соотношение Cyanobacteria/ Chlorophyta, которое характеризует ее зональную принадлежность (Гецен, 1985; Комулайнен, 2004). В альгофлоре перифитона исследованных водоемов Карельского перешейка это соотношение равно 1:2,6, что характерно для флор северных территорий. Полученное соотношение близко к приводимым для прикрепленных водорослей в водоемах Большеземельской тундры, Южной и Центральной Финляндии, Онежского озера и других северных регионов (Гецен, 1985; Комулайнен, 2004; Денисов, 2011; Копырина, 2014).

При изменении трофического уровня озер наблюдались значительные изменения процентного соотношения вклада отделов водорослей в общую биомассу перифитона. В целом, биомасса определялась вегетацией диатомовых, зеленых, цианобактерий и эвгленовых водорослей. В мезотрофных и эвтрофных озерах в различных геоморфологи- ческих районах состав доминирующих видов в целом был сходным, в малопродуктивных и гумифицированных озерах он различался. В олиготрофных и слабомезотрофных озерах Приладожья структуру биомассы определяли зеленые и диатомовые водоросли. В озерах сельгового района и Центральной возвышенности значение цианобактерий увеличивалось (рис. 2A). Так, в озерах Богородском, Воробьевом и Снетковском из зеленых водорослей доминировали Bulbochaeta mirabilis Wittrock, Bulbochaeta sp. ster., Mougeotia elegantula Wittrock, Mougeotia sp. ster., крупноклеточные Cosmarium pyramidatum Brebisson, C. turpinii Brebisson, C. connatum Brebisson, Actinotaenium cucurbita Brebisson, Closterium erenbergii Meneghini. B озерах Малом Бережном, Щукинском, Нарядном значительную роль играли Netrium digitus (Ehrenberg) Itzigsohn et Rothe, Triploceras gracile Baley, Penium silvae-nigrae Rabanus. На Центральной возвышенности в озерах Светлом и Узорном доминировали среди зеленых водорослей Oedogonium и Bulbochaete, а в озере Берестовом в массе развивалась Zygnema sp. ster. Из диатомовых преобладали виды родов Frustulia, Eunotia и Tabellaria. Состав доминирующих цианобактерий в озерах разных районов несколько различался. В озере Богородском по биомассе преобладали Microchaete tenera Thuret ex Bornet и Stigonema mamilosum (Lyngbye) C. Agardh ex Bornet et Flahault. В озере Воробьевом доминировали Tolypothrix distorta var. pennicilata (C. Agardh) Kossinskaja и Calothrix sp., а в озере Снетковском - Calothrix stellaris Bornet et Flahault и Rivularia aquatica (De Wildeman) Geitler. В озерах Светлом и Узорном превалировал Hapalosiphon fontinalis (C. Agardh) Bornet, а в озере Берестовом доминировали St. mamilosum, Nostoc sphaericum Vaucher ex Bornet et Flahault и R. aquatica. В дистрофных 
A

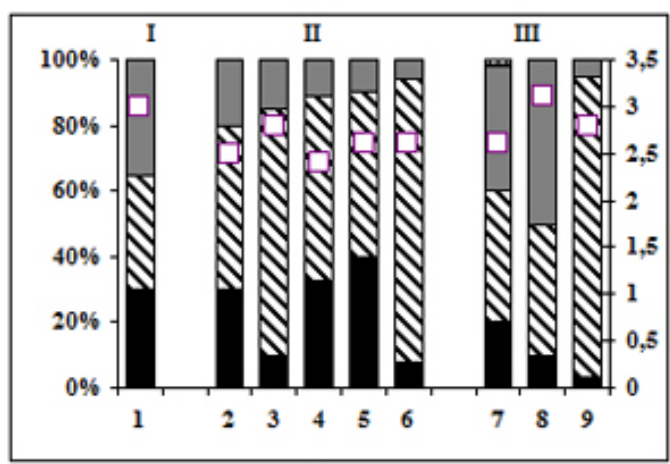

B

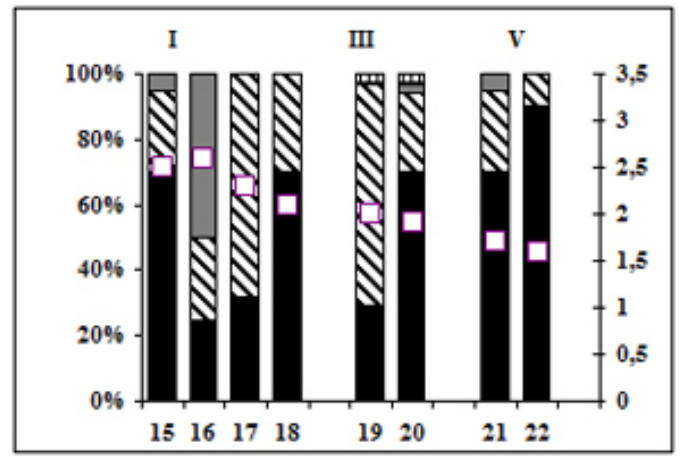

Б

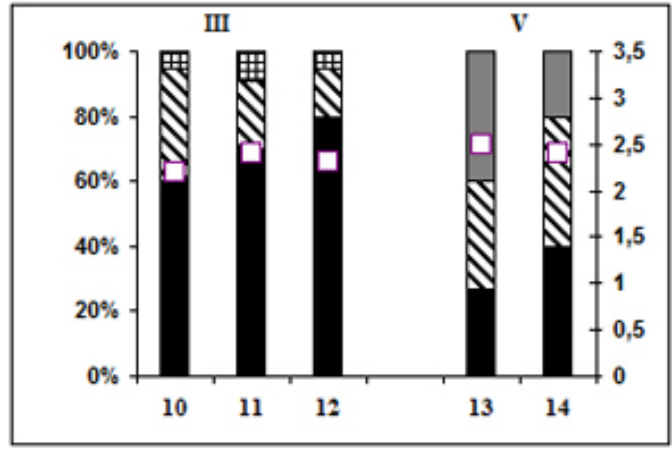

$\Gamma$

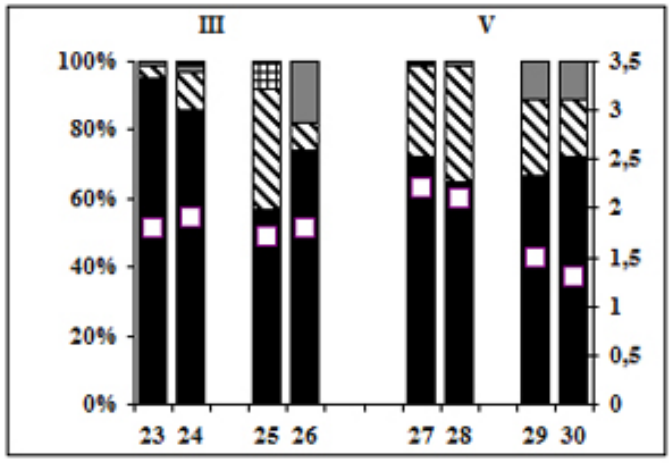

\section{диатомовые $\mathbb{\nabla}$ зеленые $\square$ цианобактерии 柬эвгленовые $\square \mathrm{H}$}

Рис. 2. Процентный вклад в общую биомассу отделов водорослей в перифитоне озер и индекс видового разнообразия (Н, бит) в июле 2011-2013 гг. Обозначения: А - малопродуктивные, Б - гумифицированные, B - мезотрофные, Г - эвтрофные и гиперэвтрофные; I-V - ландшафтные районы (обозначения как на рис. 1); озера: 1 - Богородское, 2 - Воробьево, 3 - Снетковское, 4 - Щукинское, 5 - Нарядное, 6 - М. Бережное, 7 - Узорное, 8 - Берестовое, 9 - Светлое, 10 - М. Луговое, 11 - Б. Луговое, 12 - Медведевское, 13 М. Лозовое, 14 - Затишье, 15 - Бородинское, 16 - Лесково, 17 - Б. Заветное, 18 - Горское, 19 - Мичуринское, 20 - Сиркоярви, 21 - Б. Симагинское, 22 - Чернявское, 23 - Б. Морозовское, 24 - Журавлевское, 25 Волочаевское, 26 - Вишневское, 27 - Б. Лебяжье, 28 - Красногвардейское, 29 - Балаково, 30 - М. Ладога

и гумифицированных озерах с экстремальными условиями среды (низкие рН и высокая цветность воды) формировалась весьма специфическая альгофлора.

На Центральной возвышенности в озерах М. Луговом, Б. Луговом и Медведевском преобладали диатомовые и зеленые водоросли (рис. 2Б). В перифитоне озер Приморского ландшафта наряду с зелеными и диатомовыми развивались цианобактерии (рис. $2 Б$ ). В о3. М. Луговом наиболее значительную роль в создании биомассы среди диатомовых водо- рослей играли Tabellaria fenestrata и Eunotia pectinalis, в оз. Б. Луговом - планктонный вид Aulacoseira granulata (Ehrenberg) Simonsen, в о3. Медведевском - Eunotia serra. Доминирующими зелеными водорослями в озеpax М. и Б. Луговом были Stigeoclonium aestivale (Hazen) Collins и Microspora floccosa (Vaucher) Thuret, в оз. Медведевском преобладал Klebsormidium sp., а также десмидиевые Closterium aciculare T. West, Micrasterias truncata (Corda) Brebisson и Euastrum dubium Nägeli. В Приморском районе: в оз. Зати- 
шье из диатомовых преобладали Tabellaria flocculosa и T. fenestrata, в оз. М. Лозовом Frustulia crassinervia (Brebisson) LangeBertalot и F. saxonica Rabenhorst De Toni. Из зеленых водорослей в этих озерах доминировали Mougeotia sp. и крупноклеточные десмидиевые - Netrium digitus и Cosmarium lundelii Delponte. В оз. М. Лозовом отмечено также значительное развитие Hapalosiphon fontinalis. В мезотрофных озерах сельгового ландшафта по биомассе преобладали диатомовые и зеленые водоросли, в оз. Лесково - цианобактерии (рис. 2B). Доминирующие комплексы обрастаний в этих озерах были сходны: среди диатомовых преобладали Tabellaria flocculosa, T. fenestrata, Eunotia monodon, E. pectinalis, среди зеленых - Bulbochaeta intermedia De Bary, B. insignis Pringsheim ex Hirn, Stigeoclonium farctum Berth. В оз. Лесково среди доминирующих цианобактерий были отмечены такие виды, как Microchaete calothrichoides Hansgirg, M. tenera Thuret ex Bornet, Microcoleus lacustris Farlow ex Gomont, Rivularia mesenterica Thuret ex Bornet et Flahault, которые относительно редко встречались на Карельском перешейке. В мезотрофных и эвтрофных озерах Центральной возвышенности и Приморского ландшафта биомассу перифитона также определяли диатомовые, зеленые и в меньшей степени цианобактерии (рис. 2B, $Г$ ). Среди диатомовых доминировали Ulnaria ulna, Fragilaria capucina, Cymbella cistula, C. lanceolata, Rhopalodia gibba, Epithemia turgida, Tabellaria fenestrata, T. flocculosa, Melosira varians, Navicula radiosa. Разнообразие зеленых было незначительным, в комплекс доминантов входили виды родов Spirogyra и Oedogonium. В гиперэвтрофных озерах этих же районов М. Ладога, Балаково, Волочаевское, Вишневское основу биомассы создавали диатомовые водоросли из родов Epithemia, Gomphonema, Navicula, Nitzschia.
Преобладание широковалентных видов этих родов свидетельствует о наличии органических загрязнений и эвтрофном состоянии водоемов (Щербак, Семенюк, 2011). Из зеленых водорослей в этих озерах в числе доминантов были также виды рода Oedogonium, среди цианобактерии - Aphanizomenon flos-aquae Ralfs ex Bornet et Flahault, виды родов Anabaena и Microcystis. Большинство эвгленовых водорослей в озерах этого района относились к родам Trachelomonas и Euglena (рис. $2 \Gamma$ ).

Величины индекса видового разнообразия (H, бит) в исследованных озерах изменялись в пределах от 1,2 до 3,1 (рис. 2). Наиболее низкие значения индекса отмечались для обрастаний мезотрофных, эвтрофных и гиперэвтрофных озер Центральной возвышенности и Приморского ландшафта - Б. Симагинское, Чернявское, М. Ладога, Балаково, Волочаевское, Вишневское (рис. 2B, Г). Значительно более разнообразны перифитонные сообщества в мезотрофных и некоторых эвтрофных озерах сельгового ландшафта, Приладожья и Центральной возвышенности, где индекс видового разнообразия изменялся от 2,0 до 2,5 бит (рис. $25, B$ ). Наиболее высокие величины этого индекса характерны для перифитона малопродуктивных озер всех ландшафтов.

\section{Заключение}

Исследования летнего перифитона на территории Карельского перешейка позволили выявить богатую и разнообразную флору водорослей обрастаний, отражающую черты северных альгофлор. Наибольшим своеобразием по составу водорослей выделялись малопродуктивные озера сельгового ландшафта и Приладожья с высоким таксономическим разнообразием и наличием редко встречающихся видов десмидиевых и цианобактерий, некоторые из которых внесены в Красную книгу Ленинградской области. Пе- 
рифитон малопродуктивных озер Центральной возвышенности также был достаточно разнообразным, структуру биомассы наряду с диатомовыми определяли зеленые и цианобактерии. Доминирующими видами зеленых водорослей были преимущественно зигнемовые, десмидиевые и представители родов Bulbochaeta. Доминирующие цианобактерии были представлены типичными обрастателями, характерными для чистых водоемов Фенноскандии. По мере увеличения трофности озер снижалось количество таксонов, а в биомассе заметно увеличивалась доля диатомовых водорослей. Состав доминирующих видов обрастаний в эвтрофных озерах всех ландшафтных районов был схожим, в него входили широко распространенные в водо- емах Северо-Запада виды диатомовых водорослей (родов Fragilaria, Cymbella, Ulnaria, Gomphonema) и многочисленные виды рода Oedogonium из зеленых. В гумифицированных (мезогумозных и полигумозных) озерах наблюдалось значительное снижение таксономического разнообразия, формировались сообщества, состоящие из 7-12 видов зеленых или диатомовых водорослей. На Центральной возвышенности и в Приморском ландшафте в озерах этого типа состав и доминирующие виды перифитона были различными. Процессы эвтрофирования и гумификации являются важными факторами формирования в исследованных озерах комплексов доминирующих видов перифитона и структуры их биомассы.

\section{Список литературы}

Басова С.Л. (1976) Состав, распределение и продуктивность перифитона и микрофитобентоса. Биологическая продуктивность озера Красного. Андроникова И.Н. (ред.) Л., Наука, с. 104120 [Basova S.L. (1976) Composition, distribution and productivity of periphyton and phytobenthos. Biological productivity of lake Krasnoe. Andronikova I.N. (ed.) Leningrad, Nauka, p. 104-120 (in Russian)]

Беляева П.Г. (2014) Состав и структура фитоперифитона реки Сылва (Пермский Край). Ботанический журнал, 99 (8): 903-916 [Belyaeva P.G. (2014) Composition and structure of phytoperiphyton in the Sylva river (Perm territory). Botanical Journal [Botanichesky Zhurnal], 99 (8): 903-916 (in Russian)]

Гецен М.В. (1985) Водоросли в экосистемах Крайнего Севера. Л., Наука, 165 с. [Gezen M.V. (1985) Algae in ecosystems of the Far North. Leningrad, Nauka, 165 p. (in Russian)]

Глушенко Л.А., Гольд 3.Г. (2008) Эколого-флористическая характеристика фитоперифитона Красноярского водохранилища. Перифитон и обрастание: теория и практика. Материаль Международной научно-практической конференции. Санкт-Петербург, с. 35-38 [Glushcenko L.A., Gold Z.G. (2008) Ecologo-floristic description of periphyton of the Krasnoyarsk water reservoir. Periphyton and fouling: theory and practice. Materials of International Conference. Saint Petersburg, p. 35-38 (in Russian)]

Губелит Ю.И., Никулина В.Н. (2009) Современное состояние альгоценозов озера Кривого (ББС ЗИН РАН). Биологические ресурсы Белого моря и внутренних водоемов Европейского Севера. Материаль ХХVIII Международной конференции. Петрозаводск, с. 167-171 [Gubelit J.I., Nikulina V.N. (2009) The modern state of algacenoses of the lake Krivoe (BBS ZIN RAS). Biological resources of the White Sea and inland waters of the European North. Materials of XXVIII International Conference. Petrozavodsk, p. 167-171 (in Russian)] 
Денисов Д.Б. (2011) Водорослевые сообщества различных ландшафтов Кольского Севера в оценке состояния водных экосистем. Водоросли: таксономия, экология, использование в мониторинге. Патова Е.Н. (ред.) Екатеринбург, УрО РАН, с. 275-281 [Denisov D.B. (2011) Algal communities different landscapes of the Kola North in the assessment of aquatic ecosystems. Algae: taxonomy, ecology, use in monitoring. Patova E.N. (ed.) Ekaterinburg, UrB RAS, p. 275-281 (in Russian)]

Исаченко А.Г., Дашкевич 3.И., Карнаухова Е.В. (1965) Физико-географическое районирование Северо-Запада СССР. Л., Наука, 248 с. [Isachenko A.G., Daschkevich Z.I., Karnauchova E.V. (1965) Physico-geographical regionalization of the North-West of the USSR. Leningrad, Nauka, 248 p. (in Russian)]

Комулайнен С.Ф. (1996) Перифитон рек Ленинградской, Мурманской областей и республики Карелия. Петрозаводск, Из-во КарНЦ, 39 с. [Komulainen S.F. (1996) The periphyton of the rivers of the Leningrad, Murmansk regions and Republic of Karelia. Petrozavodsk, Karelian Research Center RAS, 39 p. (in Russian)]

Комулайнен С.Ф. (2004) Экология фитоперифитона малых рек Восточной Фенноскандии. Петрозаводск, Из-во КарНЦ, 181 с. [Komulainen S.F. (2004) Ecology of the phytoperiphyton in small rivers of Eastern Fennoscandia. Petrozavodsk, Karelian Research Center RAS, 181 p. (in Russian)]

Комулайнен С.Ф. (2008) Альгофлора перифитона рек побережья Баренцева моря. Труды Карельского научного иентра РАН. Сер. Биогеография, 14: 17-31 [Komulainen S.F. (2008) Algal flora of periphyton of the rivers of the coast of the Barents sea. Proceedings of Karelian Research Center RAS. Ser. Biogeography [Trudy Karelskogo nauchnogo centra RAN. Ser. Biogeografiya], 14: 17-31 (in Russian)]

Копырина Л.В. (2014) Эпифитные водоросли озер долинь Туймаада Центральной Якутии. Новосибирск, Наука, 100 c. [Kopyrina L.V. (2014) Epiphytic algae Tuymaada valley lakes of Central Yakutia. Novosibirsk, Nauka, 100 p. (in Russian)]

Лукницкая А.Ф. (2011)К флоре пресноводных зеленых водорослей класcа Zygnematophyceae Северо-Запада России. Водоросли: таксономия, экология, использование в мониторинге. Патова Е.Н. (ред.) Екатеринбург, УрО РАН, с. 41-46 [Luknitskaya A.F. (2011) To the flora of freshwater green algae of the class Zygnematophyceae North-Western Russia. Algae: taxonomy, ecology, use in monitoring. Patova E.N. (ed.) Ekaterinburg, UrB RAS, p. 41-46 (in Russian)]

Макаревич Т.А., Остапеня А.П., Деренговская Р.А., Ковалевская Р.З., Лукьянова Е.В., Никитина Л.В. (2013) Перифитон и его использование в системе фонового мониторинга. Экологобиологические исследования водоемов Березинского биосферного заповедника. Михеева Т.М. (ред.) Минск, БГУ, с. 128-158 [Makarevich T.A., Ostapenya A.P., Derengovskaya R.A., Kovalevskaya R.Z., Lukyanova E.V., Nikitina L.V. (2013) Periphyton and its application in the background monitoring system. Ecological and biological studies of watercourses of Berezina Biosphere Reserve. Micheeva T.M. (ed.) Minsk, Belorussian State University, p. 128-158 (in Russian)]

Метелева Н.Ю. (2001) Эпифитон оз. Неро. Биология внутренних вод, (4): 32-45 [Meteleva N.Yu. (2001) Epiphyton of the lake Nero. Inland Water Biology [Biologia vnutrennich vod], (4): 32-45 (in Russian)]

Никулина В.Н. (1976) Первичная продукция и альгологические исследования некоторых рек Ленинградской области разной степени сапробности. Гидробиологические исследования 
самоочищения водоемов. Кутикова Л.А. (ред.) Л., Наука, с. 18-43 [Nikulina V.N. (1976) Primary production and algological studies of some rivers of the Leningrad region of different degrees of saprobity. Hydrobiological studies of self-purification of water bodies. Kutikova L.A. (ed.) Leningrad, Nauka, p. 18-43 (in Russian)]

Определитель пресноводных водорослей СССР (1951-1986) Т. 1-14. Голлербах М.М. (ред.) М., Л. [Identification Reference Guide of the USSR freshwater algae (1951-1986) Vol. 1-14. Gollerbah M.M. (ed.) Moscow, Leningrad (in Russian)]

Станиславская Е.В. (1999) Растительный перифитон и его продукция. Экология зарастающего озера и проблема его восстановления. Драбкова В.Г. (ред.) СПб, Наука, с. 142-152 [Stanislavskaya E.V. (1999) Phytoperiphyton and its production. Ecology of macrophyte dominated lake and a problem of its restoration. Drabkova V.G. (ed.) Saint Petersburg, Nauka, p. 142-152 (in Russian)]

Станиславская Е.В. (2004) Водоросли перифитона озерно-речной системы Вуоксы. Состояние биоченозов озерно-речной системы Вуоксы. Трифонова И.С., Беляков В.П. (ред.) СПб., ВВМ, c. 64-72 [Stanislavskaya E.V. (2004) Algae of periphyton of the Vuoksi lake-river system. Condition of biocenoses of Vuoksa lake-river system. Trifonova I.S., Beiakov V.P. (ed.) Saint Petersburg, BBM, p. 64-72 (in Russian)]

Станиславская Е.В. (2006) Структура перифитона как показатель состояния притоков Ладожского озера и реки Невы. Оиенка экологического состояния рек бассейна Ладожского озера по гидрохимическим показателям и структуре гидробиоиенозов. Трифонова И.С. (ред.) СПб, Лема, с. 91-103 [Stanislavskaya E.V. (2006) Periphyton structure as indicator of ecological condition in the Lake Ladoga tributaries and the Neva River. Assessment of the ecological condition in the rivers of the Lake Ladoga basin using hydrochemical characteristics and structure of hydrobiocenoses. Trifonova I.S. (ed.) Saint Petersburg, Lema, p. 91-103 (in Russian)]

Станиславская Е.В. (2008) Многолетние изменения состава и структуры растительного перифитона. Многолетние изменения биологических сообществ мезотрофного озера в условиях климатических флуктуаций и эвтрофирования. Трифонова И.С. (ред.) СПб, Лема, с. 65-83 [Stanislavskaya E.V (2008) Long-term changes in the composition and structure of plant periphyton. Long-term changes in biological communities mesotrophic lake under conditions of climatic fluctuations and eutrophication. Trifonova I.S. (ed.) Saint Petersburg, Lema, p. 65-83 (in Russian)]

Станиславская Е.В., Трифонова И.С. (1984) Продукционная характеристика растительного перифитона. Особенности формирования качества воды в разнотипных озерах Карельского перешейка. Андроникова И.Н. (ред.) Л., Наука, с. 192-207 [Stanislavskaya E.V., Trifonova I.S. (1984) Production characteristic of phytoperiphyton. Features of formation of quality of water in lakes of different type of the Karelian Isthmus. Andronikova I.N. (ed.) Leningrad, Nauka, p. 192-207 (in Russian)]

Станиславская Е.В., Горченко А.С. (2005) Разнообразие водорослей перифитона в притоках Ладожского озера. Новости систематики низших растений, 39: 79-98 [Stanislavskaya E.V., Gorchenko A.S. (2005) The diversity of algae of periphyton in the tributaries of lake Ladoga. News of systematics of lower plants [Novosti sistematiki nizschych rastenii], 39: 79-98 (in Russian)]

Стенина А.С. (2009) Диатомовые водоросли (Bacillariophyta) в озерах востока Большеземельской тундры. Сыктывкар, Из-во Коми НЦ УрО РАН, 176 с. [Stenina A.S. (2009) Diatoms 
(Bacillariophyta) in lakes of Bolshezemelskaya tundra East area. Syktyvkar, Komi Research Centre of Ural Department of Russian Academy of Sciences, 176 p. (in Russian)]

Судницына Д.Н. (2008) Состав и структура летнего фитоперифитона на макрофитах Псковско-Чудского озера. Перифитон и обрастание: теория и практика. Материалы Международной научно-практической конференщии. Санкт-Петербург, с. 35-38 [Sudnitsyna D.N. (2008) Summer phytoperiphyton composition and structure on Pskovsko-Chudskoe Lake macrophytes. Periphyton and fouling: theory and practice. Materials of International Conference. Saint Petersburg, p. 35-38 (in Russian)]

Трифонова И.С. (1990) Экология и сукцессия озерного фитопланктона. Л., Наука, 184 с. [Trifonova I.S. (1990) Ecology and succession of lake phytoplankton. Leningrad, Nauka, 184 p. (in Russian)]

Трифонова И.С. (2014) Современное состояние озер Карельского перешейка в условиях антропогенной трансформации. География: традиции и инновации в науке и образовании. Колл. монография по материалам ежегодной Международной научно-практической конферениии LXVII Гериеновские чтения. Санкт-Петербург, Изд-во РГПУ им. А.И. Герцена, с. 208212 [Trifonova I.S. (2014) Modern state of Karelian Isthmus lakes in conditions of anthropogenic transformation. Geography: traditions and innovations in science and education. The coll. monograph on materials of annual International scientific and practical conference LXVII Gertsenovsky readings. Saint Petersburg, RGPU of A.I. Gertsen, p. 208-212 (in Russian)]

Трифонова И.С., Афанасьева А.Л., Денисова И.А., Станиславская Е.В. (1998) Первичная продукция и трофический статус макрофитного озера Б. Ракового (Карельский перешеек). Биология внутренних вод, 3: 9-18 [Trifonova I.S., Afanasieva A.L., Denisova I.A., Stanislavskaya E.V. (1998) Primary production and trophic status macrophyte lake B. Rakovoe (Karelian Isthmus). Inland Water Biology [Biologia vnutrennich vod], 3: 9-18 (in Russian)]

Трифонова И.С., Русанов А.Г., Афанасьева А.Л., Станиславская Е.В. (2014) Растительные сообщества озер Центральной части Карельского перешейка как индикаторы их экологического состояния. Известия Самарского научного иеентра, 16 (1-4): 1034-1038 [Trifonova I., Rusanov A., Afanasieva A., Stanislavskaya E. (2014) Plant communities in the lakes of central part of Karelian Isthmus as indicators of their ecological state. Proceedings of the Samara Scientific Center [Izvestia Samarskogo nauchnogo centra], 16 (1-4): 1034-1038 (in Russian)]

Царенко П.М. (1990) Краткий определитель хлорококковых водорослей Украинской CСР. Киев, Наукова думка, 208 с. [Tsarenko P.M. (1990) Brief algae identification reference guide of Ukrainian SSR. Chlorococcales. Kiev, Naukova dumka, 208 p. (in Russian)]

Щербак В.И., Семенюк Н.Е. (2011) Использование фитомикроперифитона для оценки экологического состояния антропогенно измененных водных систем. Гидробиологический журнал, 47 (2): 27-42 [Shcherbak V.I., Semenyuk N.E. (2011) Phytomicroperiphyton application for assessing ecological condition of anthropogenically modified aquatic ecosystems. Hydrobiological journal [Gidrobiologichesky Zhurnal], 47 (2): 27-42 (in Russian)]

Chekryzheva T.A., Komulainen S.F. (2010) Algal flora of lakes and rivers in Republic Karelia (Russia). Algologia, 20 (3): 319-330

Komarek J., Anagnostidis K. (1999) Cyanoprokaryota. Teil 1/ Part 1. Chroococcales. Süsswasserflora von Mitteleuropa. Bd 19/1. Jena, Ficher Verland, 548 p. 
Krammer K., Lange-Bertalot H. (1986) Bacillariophyceae. Teil 1: Naviculaceae. Susswasserflora von Mitteleuropa 2. Stuttgart, Gustav Fischer-Verlag, 876 p.

Krammer K., Lange-Bertalot H. (1988) Bacillariophyceae. Teil 2: Bacillariaceae, Epithemiaceae, Surirrellaceae. Susswasserflora von Mitteleuropa 2/2. Stuttgart, Gustav Fischer-Verlag, 596 p.

Krammer K., Lange-Bertalot H. (1991a) Bacillariophyceae. Teil 3: Centrales, Fragilariaceae, Eunotiaceae. Susswasserflora von Mitteleuropa 2/3. Stuttgart, Gustav Fischer-Verlag, 576 p.

KrammerK., Lange-BertalotH.(1991b) Bacillariophyceae. Teil 4: Achnanthaceae. Susswasserflora von Mitteleuropa 2/4. Stuttgart, Gustav Fischer-Verlag, 437 p.

Trifonova I., Denisova I., Afanasieva A., Stanislavskaya E. (2002) The relative contributions by phytoplankton and macrophytes to primary production of two shallow lakes (Karelian Isthmus, Russia). Polish Journal of Ecology, 50 (3): 357-370 